DOI: https://doi.org/10.32839/2304-5809/2020-2-78-95

UDC 372.881.111.1

Svyrydova Larysa, Nypadymka Anna National Technical University of Ukraine "Igor Sikorsky Kyiv Polytechnic Institute"

\title{
BOOSTING STUDENTS` PRODUCTIVE AND NON-PRODUCTIVE SKILLS WITH THE USE OF VISUALS WITHIN AN ESP CLASSROOM
}

Summary. The present paper reveals the results of the research, conducted with the objective to improve students' foreign language skills with and without the help of intensive implementing visual aid tools in most of the ESP classroom activities. During the research, a focus group, consisting of 108 students of technical specialities took part in survey, which was divided into a couple of stages. The first set of questions was proposed to complete before the experiment and after it, and the second list was proposed to the students also by the completion of the research. Throughout the time of the experiment, they were offered tasks on developing the four basic language competences with the active application of images of various kinds. The paper also presents the examples of the tasks with images implementation, which could be used during the ESP lessons.

Keywords: visual aid tools, ESP, reading, listening, speaking, writing, advancing language proficiency level.

Свиридова Л.Г., Нипадимка А.С. Національний технічний університет України «Київський політехнічний інститут імені Ігоря Сікорського»

\section{ПОКРАЩЕННЯ ПРОДУКТИВНИХ І НЕПРОДУКТИВНИХ НАВИЧОК СТУДЕНТІВ ЗА ДОПОМОГОЮ НАОЧНИХ МАТЕРІАЛІВ ПРИ ВИВЧЕННІ АНГЛІЙСЬКОЇ МОВИ ПРОФЕСІЙНОГО СПРЯМУВАННЯ}

Анотація. Знання англійської мови, безперечно, набуває надзвичайно важливого значення в наші дні, оскільки все більше людей беруть участь у міжнародних наукових проектах, шукають роботу у великих корпораціях тощо. Більше того, знання англійської мови професійного спрямування відкриває освітній простір, оскільки існуе велика кількість можливостей дистанційного навчання в будь-якому університеті по всьому світу а також міжнародних між університетських програм, таким чином, студенти повинні мати можливість добре володіти спеціальною термінологією, пов'язаною зі своєю науково-дослідною сдерою, обговорювати та розуміти складні процеси, читати та розуміти технічну літературу, написану англійською мовою. Враховуючи ці фракти, важливо якомога швидше вивчити іноземну мову, щоб приділити більше часу та зосередитись на отриманні кваліфікації з певної спеціальності. Загальновідомим $е$ фракт, що візуальні засоби можуть суттево допомогти у вивченні мови; однак, все ще існує потреба у розробці завдань із більшою кількістю наочності для вивчення англійської мови професійного спрямування. У даній статті продемонстровано дослідження, яке було проведено з метою довести ефективність вдосконалення навичок з іноземної мови студентів за допомогою візуальних матеріалів, а саме зображень, фотографій, малюнків, включаючи технічні символи, а також ілюстрацій з веб-сайтів. Під час дослідження, в опитуванні, що було розподілено на декілька етапів, взяли участь 108 студентів технічних спеціальностей. Перше опитування було запропоноване до виконання експерименту та після нього, а друга, додаткова група запитань, була запропонована студентам після завершення дослідження. Протягом експерименту студентів забезпечували завданнями, що спрямовані на розвиток чотирьох базових мовних компетенцій активно застосовуючи наочні матеріали різного роду. У статті також представлені деякі приклади завдань, що виконувались зі студентами технічних спеціальностей під час занять з англійської мови професійного спрямування. Результати експерименту представлені у вигляді графіків 3 детальним описом.

Ключові слова: наочні матеріали, англійська мова професійного спрямування, розвиток мовних компетенцій, вдосконалення рівня володіння іноземною мовою.

Tntroduction. The knowledge of the English

language, undoubtedly, has become extremely essential nowadays, since more and more people are participating in international scientific projects, searching for work in big corporations, etc. Moreover, ESP knowledge opens the educational boundaries, as there is a great number of possibilities to study online at any university around the globe, thus students should be able to know the special terminology, connected with their scientific research area, discuss and understand complicated processes, read and comprehend technical literature in English. Taking into account these facts, it is important to learn the foreign language as fast as possible in order to devote more time and focus on getting a qualification in a certain speciality. It is a well-known fact that visuals can significantly help in learning a language; however, there is still a need for developing tasks with a bigger number of visuals for learning ESP. Among the visuals, used, one can mention photos, pictures, drawings, including technical ones, symbols, cartoons, illustrations from websites.

Problem statement. The peculiarities of acquiring knowledge have changed significantly over the past decade. With the high demand for learning new information fast and more effectively, the internet has become overloaded with visuals, such as graphs, charts, tables, videos and info-graphic files. At the same time, the need of sharp English language proficiency level is skyrocketing for those who search for an estimable job or, for example, wants to join academic mobility programmes or 
participate in international projects, as the world is becoming more and more globalised and communications-driven. And to a remarkable degree it concerns university graduates. Thus, educators are permanently elaborating and upgrading English language teaching methods and tools to develop learners ' communication skills. These factors have become important to be taken into consideration while planning lessons of English for Specific Purposes (ESP). The students' behaviour observation during the ESP lessons helped to conclude, that they no longer want to read long and boring texts in order to obtain new data, but they would rather watch the video or use an image. Therefore the new, advanced and innovative teaching methods should take into account these trends in information perception and learning process.

Analysis of recent research and publications. The question about the role of visual aid in learning foreign languages has been discussed by many scientists, who study cognitive aspects of linguistics, teaching methodology and others. Marina Mohd Arif stated that "visual images are becoming the predominant form of communication across a range of learning and teaching resources, delivered across a range of media and formats" [1]. Beck I., McKeown M. and Kucan L. supported this statement, noting, that pictures, being the example of visual aid in ESL classroom tend to enhance comprehension and can be used as a scaffolding tool to help students quickly associate unfamiliar words with concepts [3]. Moreover, images also are able to stimulate complex language use, promoting students to extend their abilities [2] and contribute to motivation and sense of the context of the language, following Wright A. [9].

The forms of visuals were mentioned by T. Stafford [8] and B. Goldstein [5] etc. The benefits of the integration of visuals into the learning process and namely in empowering of basic language learning skills were highlighted by various methodologists as well. Among them one can mention S. Folley [4], who researched the aid of visuals while doing listening tasks; G. Ladousse underlined the benefits of visual images, following-up speaking tasks [6]; M. Zoss revealed the positive effect of incorporating visual components into academic reading and writing practices [10]. Therefore, the thorough analysis of different methods of implementation and integration of visuals into the foreign language learning process should be conducted for optimisation of the procedure of ESL lesson and to follow the students' learning needs.

Visuals can be divided into pictures, flashcards, cartoons, presentations, interactive posters, charts and graphs, drawings etc. This paper focuses on using pictures and cartoons in the English language classroom. A. Wright underlines several reasons in favour of integrating pictures/cartoons in lesson procedure: they need minimum preparation, can be easily organized, they are interesting for students, meaningful, authentic and upgrade language skills [9].

Previously unsolved parts of the problem and aims of the article. The purpose of the present research is to identify to what extent do the visual aids in particular images is helpful in advancing foreign language comprehension, in particular when teaching ESP to the students of technical specialities and in developing their productive (speaking and writing) and non-productive (reading and listening) skills. In addition, the objective of the paper is to reveal the ways of effective incorporating of images in different activities, performed within the ESP classroom.

The main material. During the present research, the methods used were: observation, questionnaire and experiment. The focus group consisted of 108 participants, who are all non-native speakers of English, and are the students of Physical and Mathematical and Instrumentation Engineering faculties of the National Technical University of Ukraine "Igor Sikorsky Kyiv Polytechnic Institute". All the students, comprising the focus group, were randomly divided into two subgroups; let us call them A-students and B-students. The English language proficiency level of the participants from both subgroups varied between B1 and B2, which was defined with the placement test at the beginning of the semester. Throughout the period of experiment, which lasted for 4 months (one semester), A-students received material in ESP lessons, where all the activities, devoted to the development of four basic skills - listening, reading, writing and speaking - were hugely accompanied with visuals (pictures, cartoons, drawings, charts etc.). In the meantime B-students were provided with a minimum of visual aids when fulfilling the same activities as the students of A-subgroup.

Before the experiment was conducted, students were proposed to estimate their readiness and level of confidence in successful completion the tasks on the development of the following skills: listening, reading, writing and speaking, by selecting a value between 0 and 10 . The same poll was conducted at the fulfilment of the survey. Figure 1 shows the mean values of respondents ' willingness and self-confidence when doing the four types of exercises before (blue colour), and after the survey (grey colour). Suggesting the figures from 0 to 3 as low, from 4 to 7 as average and from 8 to 10 as high, one can summarize that students' mean reported self-confidence is being the average (nearly 6 points for each activity) before the experiment and showed the positive tendency (raised for 2-3 points) after the period of experiment. Moreover, if to compare these two graphs, it is noticeable, that students after the completion of the research contributed the most with performing of speaking exercises, which rose on more than 2 points and we consider it to be the biggest breakthrough in ESP learning process.

On the final stage of the experiment one more poll was carried out within the focus group. A-students were asked five questions about the effectiveness of using visuals on their ESP lessons and in each case they responded by selecting a value between 0 and 10. Figure 2 shows the mean scores on these five questions and in all cases the ratings appeared to be very positive. As we can see from this graph, the phenomenon of boosting students' speaking skills can be observed and the method of implementing visuals here proved its effectiveness. Roughly less than $20 \%$ of students demonstrated neutral attitude to the visuals in their learning activity. Overall results show that students feel the positive effect of visuals when performing listening, writing and speaking tasks. 


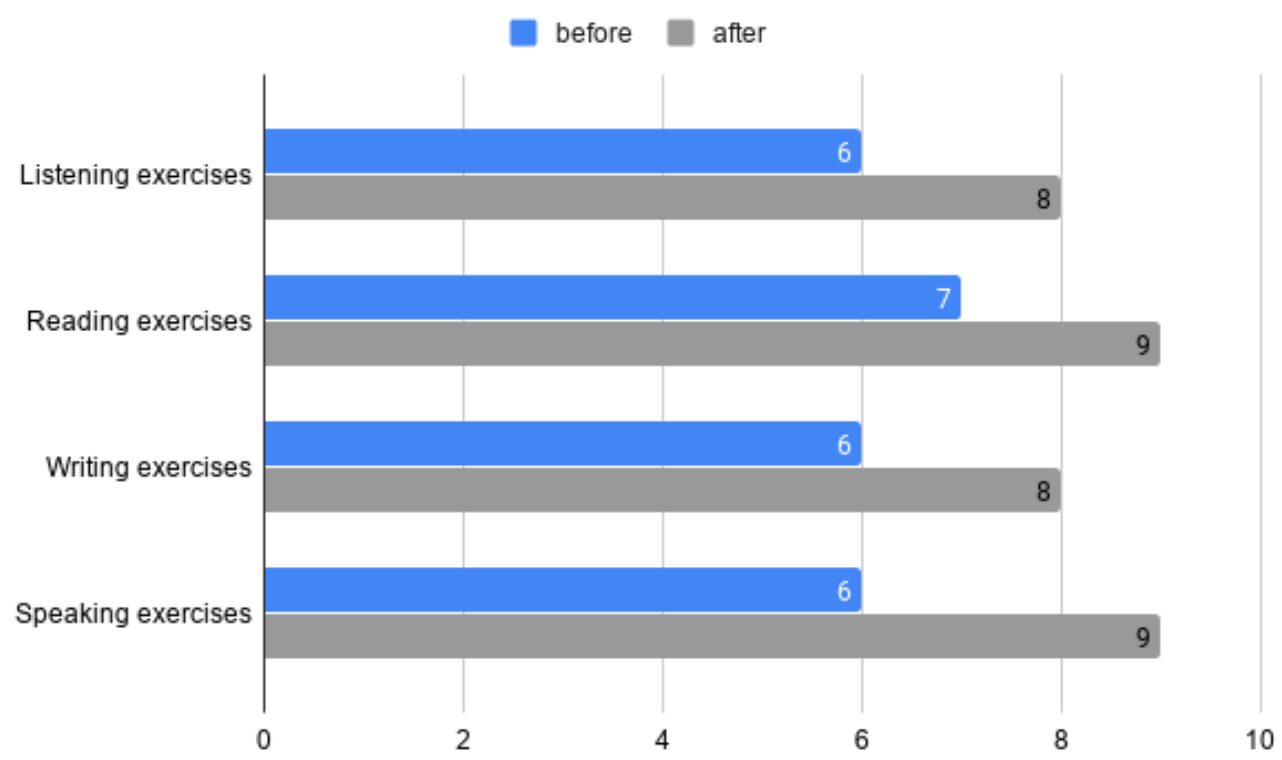

Figure 1. ESL students' views about using visuals on English lessons $(n=108)$

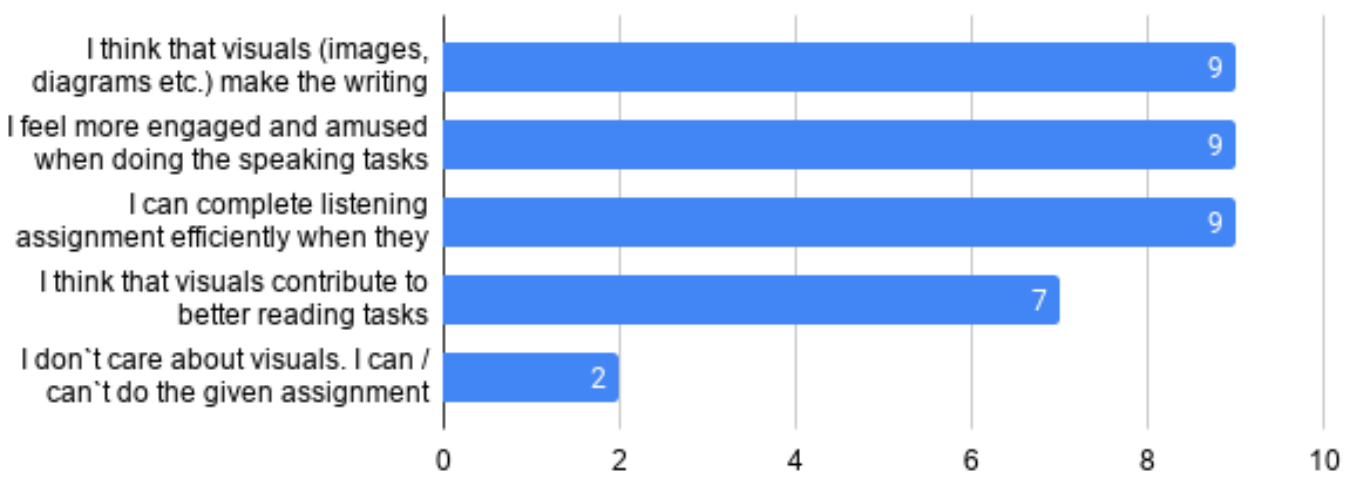

Figure 2. ESL students' views about using visuals on English lessons $(n=105)$

After the completion of the survey during the semester, A-students were offered tasks and activities within the ESP classroom, with the integration of the great number of visuals. The tasks, aimed to develop the four basic language competences are listed below (three examples to the each activity).

1. Listening skills development:

- Analyse the mind map presenting scientific method. Try to predict the plot of the audio file. Listen to the audio file carefully and put the pictures demonstrating the steps of internal combustion engine operation in the correct order.

- Look at the pictures, describe what you can see on them and try to predict the plot of the video about the Large Hadron Collider that you will watch.

- Look the pictures, presenting accidental inventions. Do you know any other objects, that were discovered accidentally? Listen to the audio and tick the images which were described.

\section{Reading comprehension:}

- Read the text about alternative energy sources and select the images from the given ones witch are relevant to the text.

- Analyse the timeline of inventions. Read short abstracts about each invention and try to guess where they should be placed on a timeline.

- Look at the photos /drawings showing famous Mathematicians. Who of these people can you rec- ognize? Read the short abstracts and match them with the personalities.

3. Writing skills development:

- Look at the manufacturing process. Describe it, using the words from a diagram.

- Match the pictures presenting shapes and materials with their names. Find the unusual building on the web and describe it, using the names of shapes and materials.

- Look at the pictures, demonstrating stages of an experiment. Put them into the correct order and write a step-by-step instruction on how to perform this experiment.

4. Speaking skills development:

- Describe a picture, giving as much information as possible using the provided vocabulary. Look at the steps of the manufacturing process. Put them into the correct order and describe.

- Look at the pictures, demonstrating the mishaps caused by differences in measuring systems. Make an assumption about what possibly might have caused the problem.

- Find the image online, demonstrating the latest invention. Show it to your partner and ask his/ her opinion about this innovation.

Having observed student's overall performance, the speed of activities accomplishment, material comprehension, engagement in the ESP learning 
process, it should be underlined that those students who were provided with the visual aid and practical exercises, based on the images analysis, were more interested and fast in tasks completion, felt more inspired to learn the new material, and demonstrated the positive feedback (that is, more students started doing home tasks and reported that the lesson was informative and helpful for understanding other disciplines, which they study within the frame of their specialization). At the same time, students demonstrated enhanced motivation while learning ESL which, in its turn, favours their overall comprehension of the subject.

Conclusion and prospects for future study. Having analysed the results of the experiment, it should be concluded that integration and incorporation of images of any of the types, listed before, into ESP learning process help to advance the student's comprehension of the studied material significantly. The subgroup which was given the tasks with the great number of visuals demonstrated that images helped them to master ESP faster and more efficiently. Therefore, we consider that the use of images and their implementation in all kinds of activities within the ESP classroom is vital. The great number of materials which is available on the internet, provides the possibility to select the relevant to the topic and appropriate visuals, which can be easily adapted to the topic of the lesson. But the images, integrated into different activities should be thoroughly selected and comply with a certain list of criteria:

- they should not break the authors' rights, every image should be followed by the reference;

- they should have a high quality, that is to have a normal resolution $(640 \times 480$ pixels is considered to be good enough for web applications, and in case of printing materials, it is preferable to take images with the highest resolution $1600 \times 1200$ );

- they should be relevant to the topic of the lesson;

- they should not contain scenes of violence, crime, religion and politics.

There are plenty of internet resources, where it is possible to download for free high-quality images. Here are some examples of websites:

www.photosforclass.com

https://www.pinterest.com

\section{References:}

1. Arif, M., \& Hashim, F. (2009). Young Learner's Second Language Visual Literacy Practices. Oxford: Inter-Disciplinary Press. Available at: http://citeseerx.ist.psu.edu/viewdoc/download?doi=10.1.1.520.2586\&rep=rep1\&type=pdf

2. Baker, L. (2015). How Many Words is a Picture Worth? Integrating Visual Literacy into Language Learning with Photographs. English Teaching Forum, vol. 53, no. 4, pp. 2-13. Available at: https://eric.ed.gov/?id=EJ1084470

3. Beck, I., McKeown, M., \& Kucan, L. (2013). Bringing words to life: Robust Vocabulary Instruction (2nd ed.). New York: The Guilford Press.

4. Folley, S. (2015). The Effect of Visual Cues in Listening Comprehension: Pedagogical Implications for Non-Native Speakers of English. Culminating Projects in English. 39. Available at: https://repository.stcloudstate.edu/engl_ etds/39 (accessed 07 December 2015).

5. Goldstein, B. (2016). Visual literacy in English language teaching: Part of the Cambridge Papers in ELT series. [pdf] Cambridge: Cambridge University Press. Available at: https://cambridge.org/betterlearning

6. Ladousse, G.P. (1983). Speaking personally: Quizzes and questionnaires for fluency practices. Cambridge: Cambridge University Press.

7. Stafford, T. (2011). Teaching visual literacy in the primary classroom: Comic books, film, television, and picture narratives. New York, NY: Routledge.

8. Wright, A. (1990). Pictures for Language Learning. Cambridge Handbooks for Language Teachers. Cambridge University Press, p. 218.

9. Zoss, M. (2009). Visual arts and literacy. In L. Christenbury, R. Bomer \& P. Smagorinsky (Eds.), Handbook of adolescent literacy research. New York, NY: The Guilford Press, pp. 183-196. 